JERZY ADAMCZYK

Wyższe Seminarium Duchowne w Radomiu

\title{
Procesje eucharystyczne w ujęciu prawa kanonicznego
}

Papież Jan Paweł II w liście apostolskim Dominicae cenae pisał, że „skoro tajemnica eucharystyczna została ustanowiona z miłości i uobecnia nam sakramentalnie Chrystusa, zasługuje zatem na nasze dziękczynienie i naszą cześć"1. Uwielbienie Chrystusa obecnego w tym Sakramencie powinno przejawiać się w różnych formach pobożności eucharystycznej, jak np.: nawiedzenia Najświętszego Sakramentu, adoracje, wystawienia, godziny święte, (czterdziestogodzinne nabożeństwa), błogosławieństwo Najświętszym Sakramentem, procesje teoforyczne, kongresy eucharystyczne. Na szczególne przypomnienie zasługuje Uroczystość Bożego Ciała, wprowadzona przez papieża Urbana IV na pamiątkę ustanowienia tej wielkiej Tajemnicy, jako akt publicznej czci dla Chrystusa utajonego w eucharystycznej Hostii².

Przedmiotem niniejszego opracowania będzie zagadnienie procesji eucharystycznych w ujęciu prawa kanonicznego. Zostaną kolejno ukazane następujące kwestie: procesje eucharystyczne jako wyraz publicznego świadectwa czci wobec Najświętszej Eucharystii, przebieg procesji i jej organizacja oraz rola biskupa diecezjalnego w kwestiach odbywania i organizacji procesji eucharystycznych.

\section{Procesje eucharystyczne wyrazem publicznego świadectwa czci wobec Najświętszej Eucharystii}

Paweł VI w encyklice Mysterium fidei pisał, że „ten kult uwielbienia, należny Sakramentowi Eucharystii, okazywał zawsze i okazuje Kościół katolicki nie tylko w cza-

${ }^{1}$ IonnNes Paulus P.P. II, Litterae Apostolicae Dominicae cenae (24 februarii 1980), nr 3, AAS 72 (1980), s. 113-148.

2 Por. tamże; por. kan. 898. 
sie obrzędów Mszy św., ale i poza nią, przez jak najstaranniejsze przechowywanie konsekrowanych Hostii, wystawianie ich do publicznej czci wiernych i obnoszenie w procesjach wśród radości thumnie zebranego ludu"3. Tak więc procesja eucharystyczna jest szczególnym wyrazem publicznego kultu Najświętszej Eucharystii poza Mszą św., należącą do jednej z trzech grup duszpasterstwa eucharystycznego ${ }^{4}$.

Dokumenty kościelne wielokrotnie ukazują kultyczny i publiczny charakter procesji, w których niesiony jest Najświętszy Sakrament. Instrukcja Eucharisticum mysterium naucza, że „chrześcijański lud składa publicznie świadectwo swej wiary i pobożności względem tego Sakramentu [Najświętszego] na procesjach, w czasie których obnosi się Eucharystię po drogach w uroczystym obrzędzie wśród śpiewu, szczególnie w Święto Bożego Ciała"5. Autorzy przypominają, że ordynariusz miejscowy winien dbać o to, aby te procesje odbywały się z godnością i bez ujmy czci należnej Najświętszemu Sakramentowi ${ }^{6}$.

$\mathrm{Z}$ kolei redaktorzy instrukcji Inaestimabile donum przypominają, że w tym, co się tyczy procesji eucharystycznych, należy przestrzegać wskazań duszpasterskich i przepisów zawartych w Rytuale Rzymskim ${ }^{7}$. Wspomniany Rytuat Rzymski, mówiąc o procesjach eucharystycznych, w czasie których celebrans niesie Najświętszą Eucharystię po ulicach, w sposób uroczysty ze śpiewem, stwierdza, że wtedy „lud chrześcijański składa publiczne świadectwo swej wiary i pobożności wobec Najświętszego Sakramentu"8. Dalej zobowiązuje się ordynariusza miejscowego, aby dołożył starań, by wspomniane procesje odbywały się z godnością i bez uszczerbku, jaki należy się temu [Najświętszemu] Sakramentowi ${ }^{9}$.

3 Paulus PP. VI, Litterae encyclicae Mysterium fidei (3 septembris 1965), nr 32, AAS 57 (1965), s. 753-774, (odtąd: Encyklika Mysterium fidei).

${ }^{4}$ Trzy grupy duszpasterstwa eucharystycznego to: 1) sprawowanie Eucharystii, w które może być włączona homilia mistagogiczna; 2) kult Eucharystii poza Mszą. św., powiązany często z nabożeństwami ludowymi i osobistą modlitwą; 3) katecheza mistagogiczna, wykłady i konferencje ascetyczne. B. Migut, Eucharystyczne duszpasterstwo, w: R. Kamiński, W. PrzYGOdA, M. FiaŁKowski (red.), Leksykon teologii pastoralnej, Lublin 2006, s. 248; zob. M. PAstuszko, Najświętsza Eucharystia wedtug Kodeksu Prawa Kanonicznego Jana Pawła II, Kielce 1997, s. 360.

5 Sacra Congregatio Rituum, Instructio Eucharisticum mysterium de cultu Mysterii Eucharistici (25 maii 1967), nr 59, AAS 59 (1967), s. 539-573.

${ }^{6}$ Por. tamie.

7 Sacra Congregatio pro Sacramentis et Cultu Divino, Instructio Inaestimabile donum (3 aprilis 1980), nr 22, AAS 72 (1980), s. 331-343, (odtąd: Instrukcja Inaestimabile donum).

${ }^{8}$ Rituale Romanum ex decreto Sacrosancti Oecumenici Concilii Vaticani II instauratum auctoritate Pauli PP. VI promulgatum, De sacra Communione et de Cultu Mysterii Eucharistici extra Missam (21 iunii 1973), nr 101, Editio typica, Typis Polyglotiis Vaticanis 1973; Święta Kongregacja Kultu Bożego, Komunia święta i kult tajemnicy eucharystycznej poza Msza święta dostosowane do zwyczajów polskich. Wprowadzenie teologiczne i pastoralne, $\mathrm{nr} 77$, Katowice 1985.

9 Por. Święta Kongregacja Kultu Bożego, Komunia święta i kult tajemnicy eucharystycznej poza Msza święta dostosowane do zwyczajów polskich, nr 77. 
Katechizm Kościoła Katolickiego zawiera następujący zapis dotyczący omawianej kwestii: „ten kult uwielbienia, należny sakramentowi Eucharystii, okazywał zawsze i okazuje Kościół katolicki nie tylko w czasie obrzędów Mszy świętej, ale i poza nią, przez jak najstaranniejsze przechowywanie konsekrowanych Hostii, wystawianie ich do publicznej adoracji wiernych i obnoszenie w procesjach"10.

Wreszcie Dyrektorium o pobożności ludowej akcentuje, że w procesjach eucharystycznych lud chrześcijański składa „publiczne świadectwo swej wiary i pobożności wobec Najświętszego Sakramentu" ", a autorzy instrukcji Redemptionis sacramentum podkreślają, że „należy dla publicznego świadectwa czci wobec Najświętszej Eucharystii urządzać, zwłaszcza w Uroczystość Ciała i Krwi Chrystusa, procesję prowadzoną po drogach publicznych, ponieważ pobożne uczestnictwo wiernych w procesji eucharystycznej w Uroczystość Ciała i Krwi Pańskiej jest łaską od Pana, która co roku napełnia radością wszystkich biorących w niej udział"12.

Kodeks Prawa Kanonicznego z 1917 r. ukazywał procesje kościelne (processiones sacra) jako akty kultu, których celem jest ożywienie w wiernych pobożności, przypomnienie odebranych dobrodziejstw Bożych i podziękowanie za nie, lub uproszenie pomocy Bożej ${ }^{13}$. Prawodawca w tym kanonie ma na myśli wszelkie procesje religijne, zwyczajne lub nadzwyczajne ${ }^{14}$, a więc i eucharystyczne, które traktowane są jako przejaw kultu Bożego (Eucharystii). Szczególnym wyrazem publicznej czci należnej sakramentowi Eucharystii jest procesja w Boże Ciało i w jego oktawę ${ }^{15}$. Na kultyczny wymiar i cel procesji, także eucharystycznych zwracał uwagę Kodeks Pio-benedyktyński w normie kan. 1295, która zobowiązywała ordynariuszy do troski o to, aby wszelkie procesje odznaczały się

${ }^{10}$ Catechismo della Chiesa Cattolica, nr 1378, Città del Vaticano 1992, thum. polskie: Katechizm Kościoła Katolickiego, Poznań 1994, (odtąd: KKK).

11 Congregatio de Cultu Divino et Disciplina Sacramentorum, Direttorio su pietà popolare e liturgia. Principi e orientamenti, (17 dicembre 2001), nr 162, Città del Vaticano 2002, tekst polski: Kongregacja ds. Kultu Bożego i Dyscypliny Sakramentów, Dyrektorium o pobożności ludowej i liturgii. Zasady i wskazania, Poznań 2003, (odtąd: DPL).

12 Congregatio de Cultu Divino et Disciplina Sacramentorum, Instructio Redemtionis sacramentum de quibusdam observandis et vitandis circa Sanctissimam Eucharistiam (25 marti 2004), nr 143, AAS, tekst polski: Kongregacja ds. Kultu Bożego i Dyscypliny Sakramentów, Instrukcja Redemtionis sacramentum, Poznań 2004, (odtąd: RS).

13 Kan. 1290 § 1 KPK z 1917 r. J. Calvo-Álvarez Procesión, w: J. Otaduy, A. Viana, J. Sedaño (red.), Diccionario general de derecho canónico, t. VI, Pamplona 2012, s. 501.

14 Kan. 1290 § 2 KPK z 1917 r.

15 Kan. 1291 KPK z 1917 r.; por. J. BAÑares, Comentario al can. 944, w: Comentario exegético al Código de Derecho Canónico, A. Marzoa, J. Miras, R. Rodríguez-Ocaña (red.), t. III, cz. I, wyd. 3, Pamplona 2002, s. 700. 
czcią i godnością ze strony uczestników oraz aby były wyeliminowane wszelkie nadużycia ${ }^{16}$.

Na procesje eucharystyczne, jako wyraz publicznego świadectwa czci wobec Najświętszej Eucharystii, wskazywały także schematy odnowionego Kodeksu. W schemacie o sakramentach z 1975 r. znajduje się następujący zapis: ubi de iudicio loci ordinarii fieri possit convenit, ut in publicum erga sanctissimam Eucharistiam venerationis testimonium, sollemnis habeatur, praesertim in festo Corporis Christi, processio etiam per vias publicas precedens ${ }^{17}$. Ordynariusze mieli dbać $\mathrm{o}$ to, by te procesje odbywały się godnie ${ }^{18}$. Podobnie o procesjach eucharystycznych jako przejawie publicznego świadectwa czci wobec Najświętszej Eucharystii oraz zabezpieczeniu przez władzę kościelną ich godności traktują schematy Kodeksu z $1980^{19}$ i 1982 r. $^{20}$

Kodeks Prawa Kanonicznego z 1983 r. stanowi, że ,gdzie, zdaniem biskupa diecezjalnego, jest to możliwe, należy dla publicznego świadectwa czci wobec Najświętszej Eucharystii urządzać, zwłaszcza w Uroczystość Ciała i Krwi Chrystusa, procesję prowadzoną po drogach publicznych”21, jak również „do biskupa diecezjalnego należy wydawanie zarządzeń o procesjach, uczestnictwa w nich i ich godności"22.

Bezsprzecznie można stwierdzić, że procesje eucharystyczne, jako wyraz publicznego świadectwa czci wobec Najświętszej Eucharystii, są szczególną realizacją kan. 898, zgodnie z którym „wierni powinni z największym szacunkiem odnosić się do Najświętszej Eucharystii, biorąc czynny udział w sprawowaniu najczcigodniejszej Ofiary, z największą pobożnością i często przyjmując ten sakrament i adorując Go z najwyższą czcią"23.

${ }^{16}$ Por. F. Baczkowicz, J. Baron, W. Stawinoga, Prawo kanoniczne. Podręcznikdla duchowieństwa, t. II, Opole 1958, s. 451.

17 Pontificia Commissio Codici Iuris Canonici Recognoscendo, Schema documenti pontificii quo disciplina canonica de sacramentis recognoscitur, Typis Polyglotiis Vaticanis 1975, can. $108 \S 1$.

18 Tamże, can. $108 \S 3$.

19 Schema Codicis Iuris Canonici, Libreria Editrice Vaticana 1980, can. 893.

${ }^{20}$ Codex Iuris Canonici, Schema novissimum iuxta placita Patrum Commissionis emendatum atque Summo Pontifici praesentatum, Typis Polyglottis Vaticanis 1982, can. 939.

${ }^{21}$ Kan. 944 § 1; por. J. Areavey, The Sacraments can. 944, w: The canon law letter and spirit a practical guide to the code of canon law. Prepared by the canon law society of Great Britain and Ireland in association with The Canadian Canon Law Society, F. MorriseY (red.), London 1999, s. 516; por. M. PAstuszko, Najświętsza Eucharystia, s. 360.

${ }^{22}$ Kan. $944 \S 2$.

${ }^{23}$ Por. J. Bañares, Comentario al can. 944, s. 702. 


\section{Organizacja i przebieg procesji}

Obowiązujący Kodeks nie zajmuje się organizacją i przebiegiem procesji eucharystycznych, przekazując tę kwestię prawu liturgicznemu i przepisom biskupa diecezjalnego ${ }^{24}$, co nie znaczy, że nie docenia ich stosowności i wartości, o czym świadczy kan. $530 \mathrm{nr}$ 6, gdzie do funkcji specjalnie powierzonych proboszczowi zalicza się ,prowadzenie procesji poza kościołem"25. Co więcej, praktyka tych procesji jest głęboko zakorzeniona w historii i tradycji Kościoła, a także polecana przez ostatnich papieży ${ }^{26}$. Instrukcja Redemptionis sacramentum przypomina, że „,chociaż w niektórych miejscach nie jest możliwe organizowanie procesji eucharystycznych, jest jednak konieczne zachowanie takiej tradycji”' ${ }^{27}$.

Gdy idzie o organizację procesji eucharystycznych, zasadniczą rolę odgrywa opinia biskupa diecezjalnego, który ocenia możliwość urządzenia takiej procesji po drogach publicznych, zwłaszcza w Uroczystość Ciała i Krwi Chrystusa ${ }^{28}$. Gdy taka możliwość istnieje, biskup diecezjalny winien wydać stosowne przepisy regulujące kwestię uczestnictwa w takich procesjach oraz ich godności ${ }^{29}$.

Najbardziej znana i najuroczyściej celebrowana jest procesja eucharystyczna organizowana w Uroczystość Najświętszego Ciała i Krwi Chrystusa (dawniej Boże Ciało) albo w innym dniu bliskim tej uroczystości ${ }^{30}$. Można też urządzać takie procesje $\mathrm{w}$ innych okolicznościach, zgodnie z przepisami prawa. W przypadku wielkiego miasta i gdy tak doradza konieczność duszpasterska, wolno za zezwoleniem biskupa diecezjalnego urządzać inne procesje w głównych dzielnicach miasta ${ }^{31}$.

${ }^{24}$ Kan. $944 \S 2$.

25 Por. J. Bañares, Comentario al can. 944, s. 700.

${ }^{26}$ Encyklika Mysterium Fidei, nr 32 ,Ten kult uwielbienia, należny Sakramentowi Eucharystii, okazywał zawsze i okazuje Kościół katolicki nie tylko w czasie obrzędów Mszy św., ale i poza nią, przez jak najstaranniejsze przechowywanie konsekrowanych Hostii, wystawianie ich do publicznej czci wiernych i obnoszenie w procesjach wśród radości tłumnie zebranego ludu"; por. Instrukcja Inaestimabile donum, $\mathrm{nr}$ 22; Rituale Romanum, De sacra Communione, $\mathrm{nr}$ 101-108; KKK, nr 1378.

${ }^{27} \mathrm{Nr} 144$.

${ }^{28}$ Kan. $944 \S 1$.

${ }^{29}$ Kan. 944 § 2; por. Rituale Romanum, De sacra Communione, $\mathrm{nr} 101$.

30 Rituale Romanum, De sacra Communione, nr 102. Prawodawca mówiąc o możliwości odbycia procesji w uroczystość Najświętszego Ciała i Krwi Chrystusa (dawniej Boże Ciało) albo innym dniu bliskim tej uroczystości ma na myśli przypadek, gdy w określonych miejscach uroczystość Bożego Ciała nie jest świętem cywilnym. Wtedy można taką procesje odbyć np. w najbliższą niedzielę przed tą uroczystością lub po niej. Por. J. Bañares, Comentario al can. 944, s. 701-702; zob. J. CalvoÁlvarez Procesión, s. 501.

31 Tamże, nr 102. Rituale Romanum, De sacra Communione mówi o ordynariuszu miejsca, aktualne prawo o biskupie diecezjalnym. 
Procesje eucharystyczne winny odbywać się po drogach, czyli poza kościołem. Instrukcja Eucharisticum mysterium wyraźnie mówi, że „chrześcijański lud składa publicznie świadectwo swej wiary i pobożności względem tego Sakramentu na procesjach, w czasie których obnosi się Eucharystię po drogach w uroczystym obrzędzie wśród śpiewu, szczególnie w Święto Bożego Ciała"32. Rituale Romanum postanawia, że ,przez procesje, w których niesie się Eucharystię po ulicach w sposób uroczysty ze śpiewem, lud chrześcijański wyraża publiczne świadectwo wiary i pobożności względem Najświętszego Sakramentu” ${ }^{33}$. Również kan. 944 KPK zarządza, aby „dla publicznego świadectwa czci wobec Najświętszej Eucharystii urządzać, zwłaszcza w Uroczystość Ciała i Krwi Chrystusa, procesję prowadzoną po drogach publicznych". O procesji po ulicach (drogach) publicznych mówi schemat KPK o sakramentach z 1975 r. ${ }^{34}$, jak również schematy Kodeksu z $1980^{35}$ i 1982 r. ${ }^{36}$

Instrukcja Redemptionis sacramentum przypomina, że „chociaż w niektórych miejscach nie jest możliwe organizowanie procesji eucharystycznych, jest jednak konieczne zachowanie takiej tradycji. Trzeba raczej poszukiwać nowych sposobów ich organizacji w dzisiejszych warunkach, na przykład w sanktuariach, w miejscach należących do Kościoła lub, za zgodą władzy świeckiej, w publicznych ogrodach" ${ }^{37}$.

Na pytanie, czy można urządzać procesję eucharystyczną wewnątrz, kościoła udzielono odpowiedzi negatywnej ${ }^{38}$. Wprawdzie żaden dokument kościelny nie zakazuje wprost odbywania procesji eucharystycznych wewnątrz kościoła, ale mówi się o obnoszeniu Eucharystii po drogach ${ }^{39}$, po drogach publicznych ${ }^{40}$, niesieniu Eucharystii po ulicach ${ }^{41}$, o przejściu z jednego kościoła do drugiego, o powrocie do

$32 \mathrm{Nr} 59$.

${ }^{33}$ Rituale Romanum, De sacra Communione, nr 101.

${ }^{34}$ Pontificia Commissio Codici Iuris Canonici Recognoscendo, Schema documenti pontificii quo disciplina canonica de sacramentis recognoscitur, Typis Polyglotiis Vaticanis 1975, can. $108 \S 1$.

35 Schema Codicis Iuris Canonici, Libreria Editrice Vaticana 1980, can. 893.

${ }^{36}$ Codex Iuris Canonici, Schema novissimum iuxta placita Patrum Commissionis emendatum atque Summo Pontifici praesentatum, Typis Polyglottis Vaticanis 1982, can. 939.

$37 \mathrm{Nr}$ 144; por. Á. MarzoA, Komentarz do kan. 941-944, w: Kodeks Prawa Kanonicznego, Komentarz. Powszechne i partykularne ustawodawstwo Kościoła Katolickiego. Podstawowe akty polskiego prawa wyznaniowego. Edycja polska na podstawie wydania hiszpańskiego, pod red. P. Majera, Kraków 2011, s. 710.

38 „Notitiae” 11 (1975), s. 64; por. W. BomBA, Kult eucharystyczny poza Msza święta, W. Świerzawski (red.), Msza święta, Kraków 1992, s. 340.

${ }^{39}$ Instructio Eucharisticum misterium, nr 59.

${ }^{40}$ Kan. $944 \S 1$; por. RS, nr 143.

${ }^{41}$ Rituale Romanum, De sacra Communione, nr 101. 
kościoła, z którego procesja wyszła ${ }^{42}$ czy o przystrojeniu trasy procesji4 ${ }^{43}$. Dyrektorium o pobożności ludowej mówi o przystrajaniu ulic i okien, składaniu kwiatów, ołtarzach, na których umieszcza się Najświętszy Sakrament, gdy procesja się zatrzymuje ${ }^{44}$.

Dokumenty kościelne mówią także o sytuacjach, w których procesja nie może się odbyć. Wypada wtedy zorganizować jakieś inne ,publiczne nabożeństwo [nie procesję] dla całego miasta albo dla głównych jego dzielnic, w kościele katedralnym czy też innych, bardziej odpowiednich miejscach"45. W organizowaniu procesji eucharystycznych należy się dostosować do miejscowych zwyczajów, zarówno gdy idzie o przystrojenie trasy procesji, jak i o zachowanie porządku wśród uczestników ${ }^{46}$.

Gdy idzie o przebieg procesji Bożego Ciała i (przez analogię) innych tego typu procesji, to „wypada, by procesja z Najświętszym Sakramentem odbywała się po Mszy świętej, w czasie której konsekruje się hostię do procesji. Można również odbyć procesję po dłuższej publicznej adoracji, którą odprawia się po Mszy świętej”77.

Urządzając procesje eucharystyczne, należy zachować miejscowe zwyczaje i zarządzenia dotyczące wystroju placów i ulic oraz kolejności uczestników procesji. Podczas drogi, jeżeli istnieje zwyczaj i przemawia za tym dobro duchowe wiernych, można urządzić krótkie nabożeństwo przy ołtarzu stacyjnym, a nawet udzielić błogosławieństwa eucharystycznego. Śpiewy i modlitwy winny być tak dobrane, aby wszyscy okazywali przez nie wiarę w Chrystusa i ku Niemu kierowali całą uwagę ${ }^{48}$.

Jeżeli procesja odbywa się zaraz po Mszy świętej, kapłan, który niesie Najświętszy Sakrament, może pozostać w szatach, w których odprawiał Mszę świętą, albo może wziąć kapę białego koloru; jeżeli natomiast procesja nie następuje bezpośrednio po Mszy świętej, wkłada kapę ${ }^{49}$. Światła, kadzidła i baldachimu, pod którym idzie kapłan niosący Najświętszy Sakrament, używa się zgodnie z miejscowymi zwyczajami ${ }^{50}$.

\footnotetext{
42 Tamże, nr 107.

${ }^{43}$ Tamże, nr 104.

${ }^{44}$ DPL, nr 162.

45 Tamże, nr 102; por. J. Bañares, Comentario al can. 944, s. 702.

46 Rituale Romanum, De sacra Communione, nr 104.

47 Tamże, nr 103; por. J. Bañares, Comentario al can. 944, s. 702.

${ }^{48}$ Rituale Romanum, De sacra Communione, nr 104.

49 Tamże, nr 105.

${ }^{50}$ Tamże, nr 106.
} 
Wypada, by procesja wyruszała z jednego kościoła i kierowała się do innego. Jeżeli jednak miejscowe warunki za tym przemawiają, może wrócić do tego kościoła, z którego wyszła. Na zakończenie procesji udziela się błogosławieństwa Najświętszym Sakramentem w kościele, do którego procesja doszła, albo w innym dogodnym miejscu, i chowa się Najświętszy Sakrament ${ }^{51}$.

\section{Rola biskupa diecezjalnego w kwestii procesji eucharystycznych}

W sprawie odbywania, organizacji i zapewnienia należytej godności procesjom eucharystycznym zasadnicza rola przypada biskupowi diecezjalnemu. Przede wszystkim to biskup diecezjalny decyduje, czy istnieje możliwość organizowania procesji eucharystycznych dla publicznego świadectwa czci wobec Najświętszej Eucharystii, zwłaszcza w Uroczystość Ciała i Krwi Chrystusa ${ }^{52}$.

Instrukcja Eucharisticum mysterium mówiła o ordynariuszu miejscowym, do którego należy osąd stosowności procesji eucharystycznych w dzisiejszych warunkach $^{53}$. Identycznie postanawiały przepisy Rytuału Rzymskiego, wydania typicznego z 1973 r. $^{54}$, jak również schemat KPK o sakramentach z 1975 r. $^{55}$, i schemat Kodeksu z $1980^{56}$. Począwszy od schematu Kodeksu z 1982 r., mówi się o biskupie diecezjalnym, który decyduje o stosowności organizowania procesji eucharystycznych ${ }^{57}$.

Według kan. $944 \S 1$, gdy biskup diecezjalny dojdzie do przekonania, że w istniejących warunkach jest możliwe i pożyteczne dla publicznego świadectwa czci wobec Najświętszej Eucharystii urządzanie, zwłaszcza w Uroczystość Ciała i Krwi Chrystusa, procesji odbywanych po drogach publicznych, to jest uprawniony wy-

51 Tamże, nr 107-108; DPL, nr 163; por. J. BAÑAREs, Comentario al can. 944, s. 702.

${ }_{52}$ Kan. $944 \S 1$; por. J. Huels, The Code of Canon Law a text and commentary, J. Coniden, T. Green, D. HeInTschel, (red.), New York 1984, s. 667; por. J. Calvo-Álvarez Procesión, s. 501.

${ }^{53} \mathrm{Nr} 59$.

${ }^{54}$ Rituale Romanum, De sacra Communione, $\mathrm{nr} 101$.

55 Pontificia Commissio Codici Iuris Canonici Recognoscendo, Schema documenti pontificii quo disciplina canonica de sacramentis recognoscitur, Typis Polyglotiis Vaticanis 1975, can. $108 \S 1$.

56 Schema Codicis Iuris Canonici, Libreria Editrice Vaticana 1980, can. 893 § 1; por. J. Calvo-Álvarez, Procesión, s. 501.

57 Codex Iuris Canonici, Schema novissimum iuxta placita Patrum Commissionis emendatum atque Summo Pontifici praesentatum, Typis Polyglottis Vaticanis 1982, can. 939 § 1; por. Kan. 944 $\S 1$, Congregaticio pro Episcopis, Direttorio per il ministero pastorale dei vescovi (22 febbraio 2004), nr 146, Città del Vaticano 2004, tekst polski: KongregaCja Do SPRAW BisKuPów, Dyrektorium o pasterskiej postudze biskupów „, Apostolorum Successores” (22 lutego 2004), Kielce 2005, (odtąd: AS), RS, nr 143. 
dać w tej sprawie zarządzenia o procesjach, uczestnictwie w nich i ich godności ${ }^{58}$, natomiast Dyrektorium o pasterskiej postudze biskupów „Apostolorum Successores” stwierdza, że „do biskupa należy wydawanie koniecznych norm dotyczących liturgii, które obowiązują wszystkich w diecezji, zawsze jednak z zachowaniem tego, co ustalił prawodawca wyższy. Takie normy mogą, między innymi, dotyczyć: (...) procesji” ‘59. Biskupi bowiem „są arcykapłanami, głównymi szafarzami Bożych tajemnic oraz moderatorami, promotorami i stróżami życia liturgicznego w powierzonym sobie Kościele" ${ }^{60}$. Dodatek do instrukcji De Synodis dioecesanis agendis wśród uprawnień legislacyjnych biskupa diecezjalnego, z których może korzystać na synodzie lub poza nim, wylicza wydawanie zarządzeń o procesjach ${ }^{61}$.

Przepisy te w pierwszym rzędzie dotyczą obowiązku urządzania procesji eucharystycznych, szczególnie tych w Uroczystość Ciała i Krwi Chrystusa. Rituale Romanum, De sacra Communione zawiera w tej kwestii następujący zapis: „wśród procesji eucharystycznych specjalne znaczenie w życiu duszpasterskim parafii lub miasta nabiera procesja urządzana zwyczajowo co roku w Uroczystość Najświętszego Ciała i Krwi Chrystusa, ewentualnie w innym, bardziej odpowiednim dniu w pobliżu wspomnianej uroczystości. Jest przeto rzeczą wskazaną, ażeby tam, gdzie pozwalają na to współczesne warunki, a sama procesja może być rzeczywiście znakiem wspólnej wiary i adoracji, była ona zachowana zgodnie z przepisem prawa" ${ }^{2}$.

W przepisach biskupa winno też znaleźć się uregulowanie przypadku procesji eucharystycznych w wielkich miastach. Według Rytuału Rzymskiego ,jeżeli (...) chodzi o wielkie miasto, i tak doradza konieczność duszpasterska, wolno za ze-

${ }^{58}$ Kan. 944 § 2; Rituale Romanum, De sacra Communione, nr 101; por. J. Calvo-Álvarez Procesión, s. 501.

59 AS, nr 146.

${ }^{60}$ Kan. 835 § 1. „Kierowanie świętą liturgią należy w sposób wyłączny do władzy kościelnej, którą jest Stolica Apostolska oraz, zgodnie z prawem, biskup diecezjalny”. Kan. 838 § 1; „Do biskupa diecezjalnego w Kościele mu powierzonym należy, w ramach przysługującej mu kompetencji, wydawanie w sprawach liturgicznych norm, które obowiązują wszystkich”. Kan. 838 $\S 4$; por. kan. 841 .

${ }^{61}$ Congregatio pro Episcopis, Congregatio pro Gentium Evangelizatione, Instructio De Synodis dioecesanis agendis (19 marti 1997), AAS 89 (1997), s. 706-721. Additamentum ad instructionem de synodis dioecesanis agendis. Pastoralia munia quae Codex Iuris Canonici concredit legum ferendarum potestati Episcopi dioecesani, nr II, „Acta Apostolicae Sedis” 89 (1997), s. 725; por. H. Sснмітz, Gesetzgebungsbefugnis und Gesetzgebungskompetenzen des Diözesanbischofs nach dem CIC von 1983, „Archiv für katholisches Kirchenrecht“ 152 (1983), s. 73.

${ }^{62} \mathrm{Nr} 102$. „Gdzie, zdaniem biskupa diecezjalnego, jest to możliwe, należy dla publicznego świadectwa czci wobec Najświętszej Eucharystii urządzać, zwłaszcza w Uroczystość Ciała i Krwi Chrystusa, procesję prowadzoną po drogach publicznych, ponieważ pobożne uczestnictwo wiernych w procesji eucharystycznej w Uroczystość Ciała i Krwi Pańskiej jest łaską od Pana, która co roku napełnia radością wszystkich biorących w niej udział”. RS, nr 143. 
zwoleniem ordynariusza miejsca [biskupa diecezjalnego] urządzać inne procesje w głównych dzielnicach miasta" ${ }^{63}$.

Normy biskupa powinny przewidywać też przypadki, gdy z różnych względów nie można urządzać procesji w Uroczystość Ciała i Krwi Chrystusa. Biskup powinien w takich przypadkach wydać zarządzenia odnoszące się do zorganizowania jakiegoś innego publicznego nabożeństwa dla całego miasta, albo dla głównych jego dzielnic, w kościele katedralnym, czy też w innych, bardziej odpowiednich miejscach ${ }^{64}$.

Biskup wydając omawiane przepisy winien uwzględniać miejscowe zwyczaje. Wspomniane zwyczaje mogą mieć bardzo różne źródła i przejawy, zależnie od okoliczności, czasu i miejsca, i w konsekwencji wymagają roztropnej opinii tego, który te zwyczaje zna (biskupa) i potrafi właściwie ocenić, biorąc pod uwagę wymienione czynniki w ich kontekście oraz wydaje odpowiednie postanowienia na temat ich zasadności, odpowiedniości, ich żywotności, organizacji i kontroli ${ }^{65}$.

Do biskupa diecezjalnego należy wydawanie zarządzeń także o uczestnictwie w procesjach eucharystycznych. Kodeks Prawa Kanonicznego z 1917 r. stosunkowo dokładnie określał uczestników procesji religijnych, w tym eucharystycznych. Tak więc w procesji Bożego Ciała odbywającej się po drogach publicznych mieli obowiązkowo brać udział: wszyscy duchowni świeccy, zakony męskie, nawet wyjęte oraz bractwa z wyjątkiem zakonników ścisłej klauzury lub mieszkających poza miastem ponad trzy tysiące kroków ${ }^{66}$.

Aktualne prawodawstwo nie podejmuje szczegółowo kwestii uczestnictwa w procesjach eucharystycznych, lecz pozostawia to prawu partykularnemu (biskupowi diecezjalnemu) ${ }^{67}$. Rytuał Rzymski mówi tylko o dostosowaniu do miejsco-

$63 \mathrm{Nr} 102$.

${ }^{64}$ Rituale Romanum, De sacra Communione, nr 102. „Chociaż w niektórych miejscach nie jest możliwe organizowanie procesji eucharystycznych, jest jednak konieczne zachowanie takiej tradycji. Trzeba raczej poszukiwać nowych sposobów ich organizacji w dzisiejszych warunkach, na przykład w sanktuariach, w miejscach należących do Kościoła, lub, za zgodą władzy świeckiej, w publicznych ogrodach". RS, nr 144.

65 Por. J. Bañares, Comentario al can. 944, s. 701; por. H. ReInHARdt, Eucharistische Prozession, w: Münsterischer Kommentar zum Codex Iuris Canonici, t. IV, K. LüDICKE (red.), Essen 1988-2001, kan. 944. „Jest jednak konieczne, aby procesje eucharystyczne odbywały się według przepisów regulujących ich przebieg, a szczególnie tych, które stoją na straży godności i poszanowania należnego Najświętszemu Sakramentowi. Nieodzowne jest również, aby typowe elementy pobożności ludowej, jak przystrajanie ulic i okien, składanie kwiatów, ołtarze, na których umieszcza się Najświętszy Sakrament, gdy procesja się zatrzymuje, śpiewy i modlitwy, były «tak dobrane, aby wszyscy okazywali przez nie wiarę w Chrystusa i ku Niemu kierowali całą uwagę». Należy także unikać wszystkiego, co może mieć posmak powierzchowności”. DPL, nr 162.

${ }^{66}$ KPK z 1917 r. kan. 1291 § 1; por. F. BĄCzKowicz, J. BAron, W. Stawinoga, Prawo kanoniczne. Podręcznik dla duchowieństwa, t. II, s. 451; por. J. BAÑAREs, Comentario al can. 944, s. 700.

${ }^{67}$ Kan. $944 \S 2$. 
wych zwyczajów organizacji procesji eucharystycznych, gdy idzie o zachowanie porządku wśród uczestników ${ }^{68}$. Wspomniane zachowanie porządku odnosi się także do zapewnienia bezpieczeństwa wiernym uczestniczącym w tych aktach kultu, gdyż zazwyczaj, szczególnie w Uroczystość Ciała i Krwi Chrystusa, bierze w nich udział wielka liczba wiernych ${ }^{69}$. Normy biskupa diecezjalnego będą także bardziej szczegółowo określały samą organizację i przebieg procesji, biorąc oczywiście pod uwagę miejscowe zwyczaje oraz powszechne przepisy liturgiczne ${ }^{70}$.

Prawodawca kodeksowy wymaga od biskupa diecezjalnego, aby wydając zarządzenia o procesjach zapewnił należny szacunek Najświętszej Eucharystii i to, by procesje eucharystyczne odbywały się z godnością. Szacunek ów ma się wyrażać przez czynny udział w sprawowaniu najczcigodniejszej Ofiary i w częstym przyjmowaniu tego sakramentu oraz w adorowaniu go z największą pobożnością. Duszpasterze zaś, wyjaśniając naukę o Eucharystii, powinni o tym obowiązku starannie wiernych pouczać ${ }^{71}$.

Cel wydawanych przepisów biskupich odnoszących się do procesji eucharystycznych ukazuje Rytuał Rzymski: „chodzi zaś o to, by odbywały się one [procesje]z godnością i bez uszczerbku dla szacunku, jaki należy się temu Sakramentowi"'72.

Warto zauważyć, że jeśli zapewnienie najwyższego szacunku dla Najświętszej Eucharystii oraz godności procesji eucharystycznych nie jest możliwe, prawodawca zabrania ich urządzania ${ }^{73}$.

\section{Wnioski}

Podsumowując powyższe rozważania, należy stwierdzić, że:

${ }^{68} \mathrm{Nr}$ 104; por. J. Bañares, Comentario al can. 944, s. 702.

${ }^{69}$ Por. J. Bañares, Comentario al can. 944, s. 701.

${ }^{70}$ „W organizowaniu procesji eucharystycznych należy się dostosować do miejscowych zwyczajów, zarówno gdy idzie o przystrojenie trasy procesji, jak i zachowanie porządku wśród uczestników. Podczas procesji, tam, gdzie istnieje taki zwyczaj i zaleca to wzgląd duszpasterski o można także przewidzieć stacje (ołtarze) wraz z udzielaniem błogosławieństwa Najświętszym Sakramentem. Spiewy i modlitwy należy dobrać w ten sposób, ażeby wszyscy ujawniali swoją wiarę w Chrystusa i kierowali uwagę tylko na Pana". Rituale Romanum, De sacra Communione, nr 104. „Jeżeli idzie o świece, okadzenia i baldachim, pod którym idzie kapłan niosący Najświętszy Sakrament, należy się dostosować do miejscowych zwyczajów. Tamże, nr 106.

71 Por. kan. 898; por. J. Bañares, Comentario al can. 944, s. 702.

${ }^{72} \mathrm{Nr} 101$.

${ }^{73}$ Por. kan. $944 \S 1$; Rituale Romanum, De sacra Communione, nr 102; por. J. AreaveY, The Sacraments can. 944, s. 516. 
1. Procesje eucharystyczne są szczególnym wyrazem publicznego kultu Najświętszej Eucharystii poza Mszą św. Należą do jednej z trzech grup duszpasterstwa eucharystycznego.

2. Wśród procesji eucharystycznych szczególne znaczenie ma procesja w Uroczystość Ciała i Krwi Chrystusa.

3. Procesje eucharystyczne, jako wyraz publicznego świadectwa czci wobec Najświętszej Eucharystii, są szczególną realizacją kan. 898, zgodnie z którym ,wierni powinni z największym szacunkiem odnosić się do Najświętszej Eucharystii, biorąc czynny udział w sprawowaniu najczcigodniejszej Ofiary, z największą pobożnością i często przyjmując ten sakrament i adorując Go z najwyższą czcią".

4. Obowiązujący Kodeks nie zajmuje się organizacją i przebiegiem procesji eucharystycznych, przekazując tę kwestię prawu liturgicznemu i przepisom biskupa diecezjalnego.

5. Gdy idzie o organizację procesji eucharystycznych, to zasadniczą rolę odgrywa opinia biskupa diecezjalnego, który ocenia możliwość urządzenia takiej procesji po drogach publicznych, zwłaszcza w Uroczystość Ciała i Krwi Chrystusa.

6. W organizowaniu i przebiegu procesji eucharystycznych należy się dostosować do miejscowych zwyczajów, zarówno gdy idzie o przystrojenie trasy procesji, jak i zachowanie porząaku wśród uczestników.

7. W sprawie organizacji, odbywania i bezpieczeństwa procesji eucharystycznych oraz zapewnienia im należytej godności zasadnicza rola przypada biskupowi diecezjalnemu, który jest władny wydać w tych kwestiach stosowne przepisy.

\section{Streszczenie}

Procesje eucharystyczne prowadzone poza kościołem są publicznym świadectwem czci wobec Najświętszej Eucharystii. Przedmiotem niniejszego opracowania jest zagadnienie procesji eucharystycznych w ujęciu prawa kanonicznego. Zostały kolejno ukazane następujące kwestie: procesje eucharystyczne jako wyraz publicznego świadectwa czci wobec Najświętszej Eucharystii, przebieg procesji i jej organizacja oraz rola biskupa diecezjalnego w kwestiach odbywania i organizacji procesji eucharystycznych.

Słowa kluczowe: procesja, biskup diecezjalny, kościół, Najświętsza Eucharystia, kult. 


\title{
Eucharistic Processions in the Light of the Canon Law
}

\begin{abstract}
Eucharistic processions carried out outside the Church are the public testimonies to honour the Holy Eucharist. The paper analyses the issue of an Eucharistic procession in the light of the Canon Law. The study successively presents the following issues: Eucharistic processions as a manifestation of the public testimony to the Holy Eucharist, the course of the procession and its organization, and the role of the diocesan Bishop in the conduct and organization of the Eucharistic processions.
\end{abstract}

Keywords: Procession, Diocesan Bishop, Church, Eucharist, Devotion.

\section{Bibliografia}

\section{Źródła}

Catechismo della Chiesa Cattolica, Città del Vaticano 1992, tłum. polskie: Katechizm Kościoła Katolickiego, Poznań 1994.

Codex Iuris Canonici, Schema novissimum iuxta placita Patrum Commissionis emendatum atque Summo Pontifici praesentatum, Typis Polyglottis Vaticanis 1982.

Congregaticio pro Episcopis, Direttorio per il ministero pastorale dei vescovi (22 febbraio 2004), Città del Vaticano 2004, tekst polski: Kongregacja do spraw Biskupów, Dyrektorium o pasterskiej postudze biskupów „Apostolorum Successores", Kielce 2005.

Congregatio de Cultu Divino et Disciplina Sacramentorum, Direttorio su pietà popolare e liturgia. Principi e orientamenti, Città del Vaticano 2002, tekst polski: Kongregacja ds. Kultu Bożego i Dyscypliny Sakramentów, $D y$ rektorium o pobożności ludowej i liturgii. Zasady $i$ wskazania (17 grudnia 2001), Poznań 2003.

Congregatio de Cultu Divino et Disciplina Sacramentorum, Instructio Redemtionis sacramentum de quibusdam observandis et vitandis circa Sanctissimam Eucharistiam (25 marti 2004), „Acta Apostolicae Sedis”, tekst polski: Kongregacja ds. Kultu Bożego i Dyscypliny Sakramentów, Instrukcja Redemtionis sacramentum, Poznań 2004. 
Congregatio pro Episcopis, Congregatio pro Gentium Evangelizatione, Instructio De Synodis diocesanis agendis (19 marti 1997), „Acta Apostolicae Sedis” 89 (1997), s. 706-721. Additamentum ad instructionem de synodis dioecesanis agendis. Pastoralia munia quae Codex Iuris Canonici concredit legum ferendarum potestati Episcopi dioecesani, „Acta Apostolicae Sedis” 89 (1997), s. 722-727.

Ioannes Paulus II, Litterae Apostolicae Dominicae cenae (24 februarii 1980), „Acta Apostolicae Sedis" 72 (1980), s. 113-148.

Paulus VI, Litterae encyclicae Mysterium fidei (3 septembris 1965), „Acta Apostolicae Sedis" 57 (1965), s. 753-774.

Pontificia Commissio Codici Iuris Canonici Recognoscendo, Schema documenti pontificii quo disciplina canonica de sacramentis recognoscitur, Typis Polyglotiis Vaticanis 1975.

Rituale Romanum ex decreto Sacrosancti Oecumenici Concilii Vaticani II instauratum auctoritate Pauli PP. VI promulgatum, De sacra Communione et de Cultu Mysterii Eucharistici extra Missam (21 iunii 1973), Editio typica, Typis Polyglotiis Vaticanis 1973.

Sacra Congregatio pro Sacramentis et Cultu Divino, Instructio Inaestimabile donum (3 aprilis 1980), „Acta Apostolicae Sedis” 72 (1980), s. 331-343.

Sacra Congregatio Rituum, Instructio Eucharisticum mysterium de cultu Mysterii Eucharistici (25 maii 1967), „Acta Apostolicae Sedis” 59 (1967), s. 539-573. Schema Codicis Iuris Canonici, Libreria Editrice Vaticana 1980.

Święta Kongregacja Kultu Bożego, Komunia święta i kult tajemnicy eucharystycznej poza Msza święta dostosowane do zwyczajów polskich, Wprowadzenie teologiczne i pastoralne, Katowice 1985.

\section{Literatura}

Bączkowicz F., Baron J., Stawinoga W., Prawo kanoniczne. Podręcznik dla duchowieństwa, t. II, Opole 1958.

Bomba W., Kult eucharystyczny poza Mszą święta, w: Świerzawski W. (red.), Msza święta, Kraków 1992, s. 325-347.

Majer P. (red.), Kodeks Prawa Kanonicznego, Komentarz. Powszechne i partykularne ustawodawstwo Kościoła Katolickiego. Podstawowe akty polskiego prawa wyznaniowego. Edycja polska na podstawie wydania hiszpańskiego, Kraków 2011.

Marzoa A., J. Miras, R. Rodríguez-Ocaña (red.), Comentario exegético al Código de Derecho Canónico, t. III, cz. I, wyd. 3, Pamplona 2002. 
Otaduy J., A. Viana, J. Sedaño (red.), Diccionario general de derecho canónico, t. VI, Pamplona 2012.

Kamiński R., W. Przygoda, M. FiaŁKowski (red.), Leksykon teologii pastoralnej, Lublin 2006.

LÜDICKE K., (red.), Münsterischer Kommentar zum Codex Iuris Canonici, t. IV, Essen 1988-2001.

Pastuszko M., Najświętsza Eucharystia wedtug Kodeksu Prawa Kanonicznego Jana Pawła II, Kielce 1997.

Schмiтz H., Gesetzgebungsbefugnis und Gesetzgebungskompetenzen des Diözesanbischofs nach dem Cic von 1983, „Archiv für katholisches Kirchenrecht” 152 (1983), s. 62-75.

MORRISEY F. (red.), The canon law letter and spirit a practical guide to the code of canon law. Prepared by the canon law society of Great Britain and Ireland in association with The Canadian Canon Law Society, London 1999.

Coriden J., T. Green, D. Heintschel (red.), The Code of Canon Law a text and commentary, New York 1984.

JERZY ADAMCZYK - dr hab. prawa kanonicznego; prezbiter diecezji radomskiej; wykładowca WSD w Radomiu; e-mail: ksjerzyad@wp.pl. 